\title{
Layouts for small freestall dairy barns: Effect on milk yield for cows in different parities
}

\author{
G. Næss, ${ }^{*} \dagger^{1}$ K. E. Bøe,‡ and 0. Østerås $\S$ \\ *Norwegian University of Life Sciences, Department of Mathematical Sciences and Technology, PO Box 5003, NO-1432 Aas, Norway \\ †North Trøndelag University College, Faculty of Agriculture and Information Technology, PO Box 2501, NO-7729 Steinkjer, Norway \\ ¥Norwegian University of Life Sciences, Department of Animal and Aquacultural Sciences, NO-1432 Aas, Norway \\ §Norwegian School of Veterinary Science, Department of Production Animal Clinical Sciences, N-0033 Oslo, Norway
}

\begin{abstract}
Freestall housing for dairy cows has many different layouts and the space allocated for cows differs considerably. The objective of the present study was to investigate possible associations between barn layout and milk yield for different parities in small dairy freestall barns. Layouts of 204 Norwegian freestall barns constructed during the period from 1995 to 2005, and with a mean herd size of $42.7 \pm 15.5$ cows, were obtained and merged with milk yield data and calving interval, for each parity, from the Norwegian Milk Recording System (NDHRS). The milk yield data set contained 20,221 different lactations from these 204 herds. Both simple mixed models, including the different explanatory variables one by one together with parity, calving interval, and herd as random effect, and a final mixed model, including all significant explanatory variables, were created. According to variables tested in this study, the final mixed model estimates show that only primiparous cows benefit significantly from increased free space allocation. Milk yield was generally higher in automatic milking system barns compared with that in barns with milking parlors, but not for primiparous cows. Milk yield was higher for all parities for barns using separation pens in accordance with the recommendations. Barns with 2 or more dead-end alleys had lower milk yield compared with that from layouts without dead-end alleys. Primiparous cows benefited from water troughs located for easy access and responded with increased milk yield. In $10 \%$ of the barns, the water trough capacity was less than $47 \%$ of the recommendations, and all parities benefited from a water trough capacity higher than this level. Higher parities had increased milk yield when water trough capacity was more than $80 \%$. Feed bunk space, number of freestall rows, and the location of freestalls had no significant effect on the milk yield. The present study
\end{abstract}

Received May 10, 2010.

Accepted November 17, 2010.

${ }^{1}$ Corresponding author: geir.nass@hint.no showed that increased space and improved access to water is beneficial to primiparous cows, whereas layouts without dead-end alleys and improved water capacity is beneficial for all cows in freestall systems.

Key words: freestall housing, layout, milk yield, lactation

\section{INTRODUCTION}

Even in small dairy freestall barns, the space allowance $\left(\mathrm{m}^{2} / \mathrm{cow}\right)$ may vary considerably (Næss and Bøe, 2010). Reducing the space will, of course, reduce the building costs (Gazzarin and Hilty, 2002), but may also influence production parameters negatively. Data from other production animals like growing-finishing pigs (NCR-89 Committee on Confinement Management of Swine, 1986; Brumm and Miller, 1996), poultry (Dozier et al., 2006), and cattle (Ingvartsen and Andersen, 1993) all show that relevant production parameters are impaired by reduced space allowance. Also, for dairy heifers, daily gain and feed intake decreased with decreasing resting area (Fisher et al., 1997; Mogensen et al., 1997). Data from dairy sheep (Caroprese et al., 2009) show that reducing the space also caused a reduction in milk yield. For dairy cows, the effect of limited space is less well documented. Fregonesi and Leaver (2002) did not find any effect of reduced total space in freestall systems, whereas Henneberg et al. (1986) found reduced milk yield when reducing alley widths. Graves (1989) observed that herds with a high milk yield often seem to have larger space per cow, and Simensen et al. (2010) found that milk yield increased with increasing herd sizes in small freestall dairy barns.

Unlike the rather uniform space provided for production animals like pigs, sheep, and poultry, the freestall system is divided into separate areas for lying (the freestalls), feeding, walking, and milking. Recommendations for dimensions of freestalls differ (CIGR, 1994; Bickert et al., 2000; ASABE, 2006), although freestall dimensions seem to have no effect on behavior and lying time (Tucker et al., 2004). Still, this variation in freestall dimensions has only a limited effect on the 
total area allocated for cows (TCA). Overstocking $(>1$ cow per freestall), however, will certainly influence the area measured as TCA. It may also have a negative effect on the lying behavior of the cows by reducing the lying time (Friend et al., 1977; Fregonesi et al., 2007; Krawczel et al., 2008). Recommendations for alley widths differ (CIGR, 1994; Bickert et al., 2000; Graves, 2000), and alley widths do have a significant effect on the TCA. However, only one scientific study has focused on the negative effects of reduced alley width (Henneberg et al., 1986). The organization of the alleys is important to achieve optimal cow traffic and deadend alleys should be avoided (Smith et al., 2000).

Reducing feed bunk space has had a negative effect on feeding behavior (Friend et al., 1977; DeVries et al., 2004), especially for low-ranked cows (Huzzey et al., 2006). In several recommendations (CIGR, 1994; McFarland, 2000), the importance of an adequate water supply is pointed out. Cows are found to prefer, and to drink more from, larger troughs (Pinheiro Machado Filho et al., 2004; Teixeira et al., 2006). However, documentation of possible negative effects on milk yield from reducing feed bunk space or amount of water supply is scarce.

The importance of separate areas for special needs cows is emphasized in all recommendations (Cook and Nordlund, 2004; Kammel and Graves, 2007), but data from Norwegian herds show that these areas often are minimized, or even not present (Næss and Bøe, 2010). It is most likely that the absence of such areas will influence milk production, but no relevant data seem to exist.

Primiparous cows are found to benefit from separate grouping from older animals by increased feed intake and productivity (Krohn and Konggaard, 1979; Grant and Albright, 2001). Kjæstad and Myren (2001a,b) found that approximately one third of the heifers refused to use the freestalls for the first 2 wk after being transferred to the lactating cow group. However, separating primiparous cows is not feasible in small herds.

The aim of this study was to investigate possible associations between barn layout and milk yield for different parities in small dairy freestall barns.

\section{MATERIALS AND METHODS}

\section{The Herds}

This study was part of a larger descriptive and crosssectional project on freestall housing. Because we did not have a complete list of freestall barns in Norway, a questionnaire was sent to all dairy advisors and a list of 2,400 farms was obtained. These farmers received a questionnaire covering several aspects of their housing system. In order to be included in the final study, farmers had to fulfill our inclusion criteria: have a freestall barn, volunteer to participate, have a herd size $>20$ standardized cow years based on the year 2005 (cow year $=$ number of days from first calving to culling within one year, divided by 365), and have a barn built in the years 1995 to 2005 . As we expect some housing systems to be common in the future, all barns with automatic milking system (AMS; $\mathrm{n}=44$ ), with solid concrete floors $(\mathrm{n}=105)$, or rubber solid floors ( $\mathrm{n}$ $=24$ ) in the alleys were included in the barns under study. Traditionally, freestall barns in Norway have been constructed with slatted floors, and such buildings were only included if they were located in the same municipality as the farms mentioned above. The final database included 232 freestall dairy herds located all over Norway. Three herds with the Jersey breed were excluded, and 25 herds were excluded because information about floor plans was missing. The final material in this study, thus, included 204 herds.

\section{Observations on Barn Layout}

During the period from September 2006 to May 2007 all of the barns were visited once by 1 of 5 trained observers. In the training period, the individual observers registered at the same farm. The figures and observations were compared and discussed in order to harmonize the results. Farmers were asked to provide detailed drawings used during the barn-building process. Approximately $80 \%$ of the farmers were able to provide such drawings. On these farms, all main dimensions of the building were measured to be sure that the drawings were correct. For the other buildings, all relevant dimensions for the layout were measured during the field work. For more details, see Næss and Bøe (2010). The layout variables tested in the models are listed in Table 1. For further information about classes and number of cases, see Table 2.

\section{Cow and Milk Yield Data}

Milk yield data, parity, and calving interval for each individual lactation, was obtained from the Norwegian Dairy Herd Recording System (NDHRS; Østerås et al., 2007). In Norway, milk yields are gathered monthly on the farms and reported to the NDHRS. From these data, a pre-estimated 305-d milk yield exists in the database. This 305-d milk yield was derived from lactations that started with a normal calving in 2005, 2006, or 2007. All lactations with less than 305 DIM were deleted, as well as lactations with more than 450 DIM (considered to be abnormally long lactations). The final data set was also restricted to the purebred Norwegian 
Table 1. Layout variables tested in the models

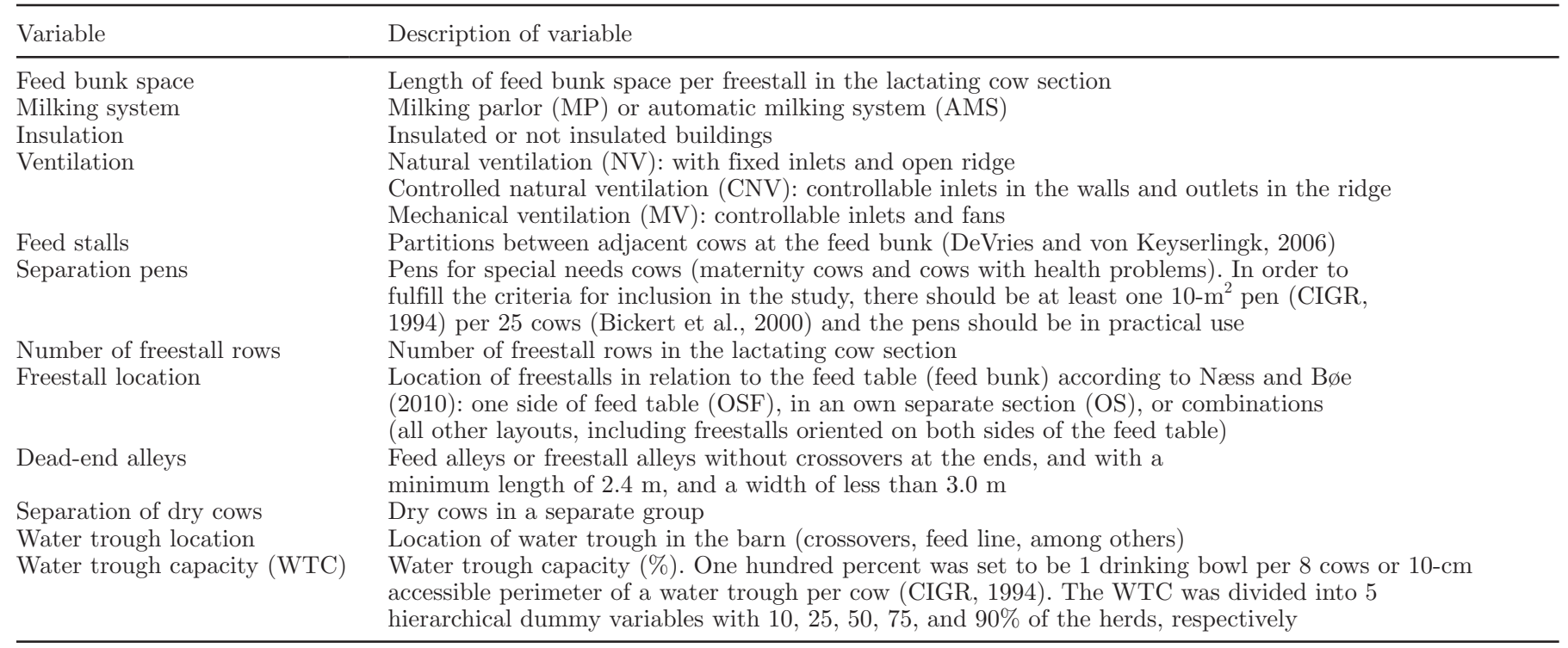

Red Breed which is about $94 \%$ of the dairy cattle population in Norway. The milk yield data set comprised 20,221 different lactations using 12,118 different cows and 204 different herds.

\section{Definitions of Variables Extracted from NDHRS}

Milk yield was defined as the milk yield calculated for a 305-DIM lactation. The calving interval was defined as the number of days between 2 calvings. Parity was defined as lactation number (lactation 4 and higher were merged into one group in the analysis). Herd size was defined as the mean number of cows in the barn (lactating and dry cows) reported as standardized cowyear (the sum of the number of days from first calving to culling within 1 calendar yr divided by 365 ). Free space allocation (FSA) was defined as the free space $\left(\mathrm{m}^{2}\right)$ allocated per standardized cow-year, including freestalls, alleys, and crossovers (Næss and Bøe, 2010).

\section{Models and Statistical Analyses}

Statistical analyses were performed using Proc Mixed in SAS (version 9.1, SAS Institute Inc., Cary, NC) with 305-d milk yield for each lactation as the dependent variable. As independent fixed effect variables, both parity and calving interval for that specific lactation were forced into the model, as these 2 variables have an effect on milk yield. Additionally, all relevant variables from design and management of the freestall barns were introduced into the model one by one. In all models the herd identity was included as random effect with the option $\mathrm{dffm}=$ satterth to adjust for lactations within the same herd being correlated or not independent of each other. The option satterth performs a general Satterthwaite approximation for the denominator degrees of freedom. The model building started with including one extra variable separately into the model including parity, calving interval, and herd as random effect according to Dohoo et al. (2003):

$$
\begin{aligned}
Y_{i}=\beta_{0}+ & \beta_{1} \times \text { parity }_{\mathrm{i}}+\beta_{2} \times \text { calving interval }_{\mathrm{i}} \\
& +\beta_{3} \times X_{1 i}+\mu_{\text {herd }(i)}+\varepsilon_{i}
\end{aligned}
$$

where $Y_{i}=305$-d milk yield in kilograms for individual lactation, $\beta_{0}=$ intercept, $\beta_{1}=$ fixed effect of parity, $\beta_{2}=$ fixed effect of calving interval, $\beta_{3}=$ fixed effect of the included separate variable $X_{1 i}, \mu_{\text {herd }(i)}=$ random effect on herd level containing the $i$ th lactation, and $\varepsilon_{i}$ $=$ random effect for the $i$ th lactation.

The Akaike information criterion (AIC) and significance level were recorded for all of these models separately. Thereafter, a final model was constructed using a forward stepwise procedure by including the additional fixed effect of the variable that had the lowest and most significant AIC level from the separate models, one by one. The starting model was Equation [1], including the variable that gave the lowest AIC, and including the variables one by one, according to the AIC value from Equation [1]. For each variable the interaction between parity and the fixed effect variable was also tested in the model. All variables with $P<0.10$ were tested by the forward stepwise procedure. If neither the newly introduced fixed effect variable nor the interaction term with parity was significant, this variable was excluded 
Table 2. Effect of housing conditions on milk yield (results from simple mixed models where one fixed effect variable is adjusted for parity, calving interval, and random herd effect)

\begin{tabular}{|c|c|c|c|c|c|}
\hline Variable & Class & $\mathrm{n}$ & Estimate & $\mathrm{SE}$ & $P$-value \\
\hline Free space allocation & Continuous & 20,221 & 43.86 & 25.90 & 0.09 \\
\hline Milking system & Milking parlor (MP) & 16,266 & 0.00 & & \\
\hline \multirow[t]{2}{*}{ Insulation } & Insulated & 17,266 & 154.98 & 151.82 & 0.31 \\
\hline & Not insulated & 2,955 & 0.00 & & \\
\hline Ventilation & Natural ventilation $(\mathrm{NV})$ & 3,403 & 0.00 & & \\
\hline \multirow[t]{2}{*}{ Feed stalls } & Yes & 2,285 & 338.44 & 180.38 & 0.06 \\
\hline & No & 17,936 & 0.00 & & \\
\hline \multirow[t]{3}{*}{ Separation pens } & Guidelines not fulfilled & 12,122 & -330.74 & 113.87 & 0.004 \\
\hline & Missing & 2,443 & -20.99 & 179.62 & 0.91 \\
\hline & Guidelines fulfilled & 5,656 & 0.00 & & \\
\hline Number of freestall rows & $1-2$ rows & 5,721 & -97.79 & 128.39 & 0.45 \\
\hline \multirow[t]{3}{*}{ Dead-end alleys } & One dead-end alley & 5,233 & 16.04 & 124.54 & 0.90 \\
\hline & 2 or more dead-end alleys & 4,727 & -323.62 & 123.85 & 0.01 \\
\hline & No dead-end alley & 10,261 & 0.00 & & \\
\hline \multirow[t]{2}{*}{ Separation of dry cows } & Yes & 8,081 & 183.82 & 106.32 & 0.09 \\
\hline & No & 12,140 & 0.00 & & \\
\hline \multirow[t]{5}{*}{ Water trough location } & At the feed bunk (FB) & 1,894 & -12.28 & 184.64 & 0.95 \\
\hline & In front of the first freestall row (FFR) & 1,912 & 37.85 & 198.20 & 0.85 \\
\hline & In crossovers $(\mathrm{CO})$ & 4,964 & -70.54 & 142.22 & 0.62 \\
\hline & Next to a wall (NTW) & 5,063 & -257.86 & 137.49 & 0.06 \\
\hline & Combinations & 6,388 & 0.00 & & \\
\hline \multirow[t]{4}{*}{ Water trough capacity (WTC) } & WTC $<47 \%$ & 1,832 & -441.29 & 174.80 & 0.01 \\
\hline & $\mathrm{WTC}>47 \%$ & 18,389 & 0.00 & & \\
\hline & WTC <60\% & 4,916 & -171.14 & 119.41 & 0.15 \\
\hline & WTC > $>60 \%$ & 15,305 & 0.00 & & \\
\hline
\end{tabular}

${ }^{1}$ Mean herd size $42.7 \pm 15.5$ cows, range $17.6-80.2$; free space allocation $7.94 \pm 1.78 \mathrm{~m}^{2}$ per cow, range $3.5-18.5$; feed bunk space $0.56 \pm 0.16 \mathrm{~m}$ per cow, range $0.26-1.05$.

from the model. If the fixed effect was not significant but the interaction term was significant, both the fixed simple effect and the interaction term were included for further testing, including more variables. At this point, the significant level was set at $P<0.05$. The final model can, thus, be expressed as

$$
\begin{aligned}
Y_{i}= & \beta_{0}+\beta_{1} \times \text { parity }_{\mathrm{i}}+\beta_{2} \times \text { calving interval }_{\mathrm{i}}+\beta_{3} \\
\times & \left(X_{1 i}\right)+\ldots+\beta_{k} \times\left(X_{k i}\right)+\beta_{4} \times \text { parity }_{\mathrm{i}} \times X_{1 i} \\
& +\ldots+\beta_{k} \times \text { parity }_{\mathrm{i}} \times X_{k i}+\mu_{h e r d(i)}+\varepsilon_{i},
\end{aligned}
$$

where the parameters in Equation [2] have the same meaning as those in Equation [1] and $\beta_{3} \times\left(X_{1 i}\right)+\ldots$ $+\beta_{k} \times\left(X_{k i}\right)=$ fixed effect of the included variables
$X_{1 i} \ldots X_{k i}$ and $\beta_{4} \times$ parity $_{\mathrm{i}} \times X_{1 i}+\ldots+\beta_{k} \times$ parity $_{\mathrm{i}}$ $\times X_{k i}=$ interaction between parity and relevant $X_{1 i}$ $\ldots X_{k i}$.

\section{RESULTS}

The 305 -d milk yield was $6,778 \mathrm{~kg}$ (mean) with an SD of $\pm 1,595 \mathrm{~kg}$. The minimum and maximum were 1,102 and 14,640 respectively. The results from the separate model, including the different explanatory variables one by one, together with parity, calving interval, and herd as random effect are presented in Table 2, together with the corresponding $P$-values. The result from the final model, including all significant fixed effect variables, is presented in Table 3, together with the corresponding $P$-values. 
The variables calving interval and parity were included in all simple models and were highly significant even in the final model (Table 3). Interestingly, significant interactions existed between parity and free space allocation, milking system, ventilation, water trough location, and water trough capacity (WTC) $<80 \%$ (Table 3).

Milk yield increased with increased herd size in the simple model; however herd size was excluded in the final model, as $P$-value $>0.05$. Increased free space allocation tended to be associated with higher milk yield in the simple model, but in the final model, the estimates show that only primiparous cows benefit from increased free space allocation (Table 3).

In general, no significant increase in milk yield existed in herds with AMS. However, taking into account the interaction with parity, milk yield was significant higher in AMS barns compared with that in barns with milking parlors. However, for primiparous cows this effect was negligible (Table 3) and nonsignificant.

Milk yield was significantly higher in barns with controlled natural ventilation and mechanical ventilation (insulated barns) compared with that from barns with natural ventilation (typical for uninsulated barns, cold barns). The differences in milk yield were more pronounced for higher parities.

Feed bunk space had no significant effect on the milk yield. Barns with feed stalls tended to have higher milk yield. However, this effect was not found to be significant in the final model. Herds that kept dry cows together with lactating cows tended to produce less milk compared with those in barns with a separate section for dry cows, but this effect was not found to be significant in the final model either. Both in the simple and final models, and for all parities, the milk yield was higher for barns using separation pens in accordance with the recommendations.

The number of freestall rows and the location of freestalls had no significant effect on the milk yield. Barns with 2 or more dead-end alleys had a lower milk yield compared with that from layouts without deadend alleys. Layouts with one dead-end alley did not differ from those with no dead-end alleys in any of the models in terms of milk yield.

In the simple model, location of water troughs next to the wall tended to result in lower milk yield. The final model shows that only primiparous cows produced less milk in barns with water troughs located next to the wall. They also benefited from water troughs located in front of the first freestall row. For all other parities the location of water troughs had no effect on milk yield.

In $10 \%$ of the barns, the water trough capacity was less than $47 \%$ of the recommended capacity, and here the milk yield was significantly lower. Even in barns with less than $104 \%$ of the recommended water trough capacity, the milk yield tended to be lower in the simple model. According to the final model, all parities benefit from a water trough capacity higher than $47 \%$, whereas only cows in higher parities benefit from water trough capacity higher than $80 \%$.

\section{DISCUSSION}

Our statistical models consisted of 2 variables that are unique at lactation level (parity and calving interval) and several variables that are specific for the herd. For the herd-specific variables, no variation within the herd was observed, and the dependent variable of 305-d milk yield is correlated within herds. This problem of dependent (correlated) data is taken care of by using mixed models with herd as a random effect. The herd random variation accounts for $24 \%$ of the total variation, which demonstrates that lactations within the same herd are more equal than lactations among herds. This herd variation has to be accounted for to give correct results, which are done by using mixed models (Dohoo et al., 2003). By using the forward stepwise inclusion method for the full model, we also had a very good overview of possible confounders and, eventually, effects of correlated variables. Interaction with parity was very important for the results of this material and can be illustrated by one example: in general, no significant increase was found in milk yield for herds using AMS, and this was unexpected due to previous research (Svennersten-Sjaunja and Pettersson, 2008). However, by including the interaction term of parity with milking system (AMS or not), a very significant increase in milk yield for parities higher than first parity was identified. This would be impossible to reveal in a much simpler model by calculating the means at the herd level and running the models in a more simple straightforward way at the herd level. A simple herd-level model also would not take into account all of the information we had on variation between lactations within herds. Herdlevel analyses, thus, were not chosen. In addition, the risk of having ecologic bias or group-level confounding effects always exists when doing analyses at group level. One should, therefore, be careful when making inferences about individuals based on group-level analyses (Dohoo et al., 2003), which makes the 2-level model, as in this study, a much better approach.

The results from the present study show that it is primiparous cows, especially, that benefit from increasing space and easy access to the barn facilities (water, feed), and respond by increased milk yield. This statement is supported by Grant and Albright (2001) who, in their review, conclude that primiparous cows benefit from being grouped separately by increased feed intake 
Table 3. Estimates for milk yield for significant housing conditions in the final mixed model including 20,221 different lactations from 204 herds

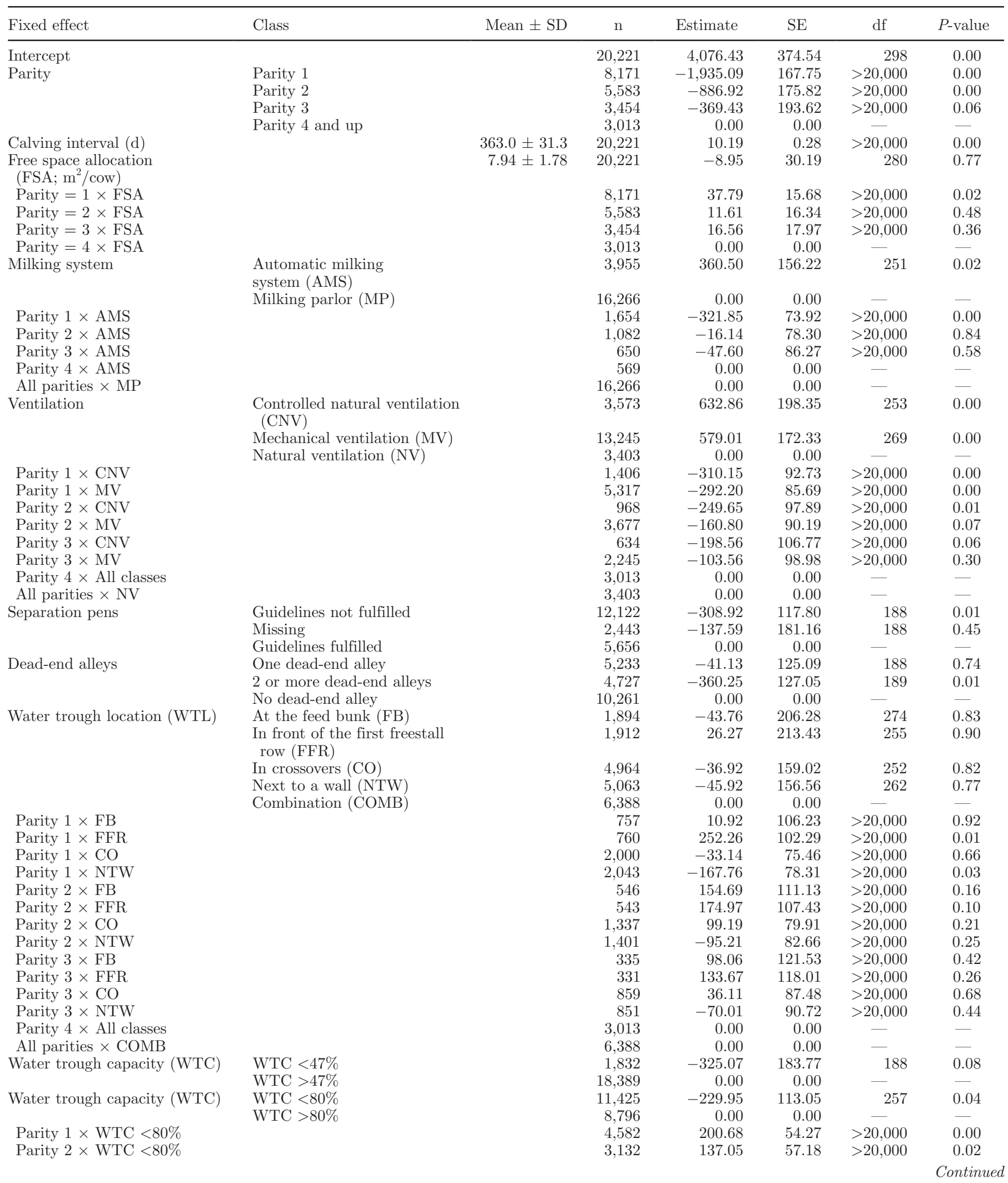


Table 3 (Continued). Estimates for milk yield for significant housing conditions in the final mixed model including 20,221 different lactations from 204 herds

\begin{tabular}{|c|c|c|c|c|c|c|c|}
\hline Fixed effect & Class & Mean \pm SD & $\mathrm{n}$ & Estimate & SE & df & $P$-value \\
\hline Parity $4 \times$ & & & 1,738 & 0.00 & 0.00 & - & - \\
\hline All parities & & & 8,796 & 0.00 & 0.00 & - & - \\
\hline \multicolumn{8}{|c|}{ Random effects } \\
\hline Herd $^{1}$ & & & 204 & 468,040 & 50,092 & & $<0.001$ \\
\hline Random err & & & 20,221 & $1,467,657$ & 14,682 & & $<0.001$ \\
\hline
\end{tabular}

${ }^{1}$ Random effect on herd level $=24.2 \%$.

and productivity. Krohn and Konggaard (1979) quantified this increase in milk yield to be 5 to $10 \%$. However, in small herds, primiparous cows are often kept together with lactating cows.

The generally higher milk yield in herds using AMS is supported by the conclusion in the review article of Svennersten-Sjaunja and Pettersson (2008). However, they also reported that some studies have shown similar milk yield in herds with AMS and manual milking. In the present study, no increase in milk yield could be seen for primiparous cows. Looking at all animals in the herd as a whole might be the reason why some studies have found similar milk yields. Spolders et al. (2004) found that primiparous cows visited the milking unit more often than did multiparous cows, but the increased milking frequency had no effect on milk yield. Another statement that supports our findings is that cows of low social rank, as primiparous cows often are, spend more time waiting in line in front of the milking unit (Melin et al., 2006).

Several authors have reported reduced feeding time when the feed bunk space is reduced (DeVries et al., 2004; Huzzey et al., 2006), but Olofsson (1999) observed that the cows compensated by increased consumption rate when feed bunk space was reduced. This may explain the findings of Friend et al. (1977), that the actual feed intake was not reduced until the feed bunk space was less than $0.2 \mathrm{~m}$ per cow. As mean linear feed bunk space was $0.59 \mathrm{~m}$ (minimum $0.26 \mathrm{~m}$ ) per freestall (Næss and Bøe, 2010) in the present study, even lowranked cows seem to have had sufficient access to the feed table. Hence, it is not surprising that feed bunk space had no significant effect on milk yield.

The number of freestall rows will normally influence feed bunk space per freestall (Mentink and Cook, 2006). However, just as feed bunk space, the number of freestall rows had no effect on milk yield. Even though the location of freestalls in a separate section or in different combinations has been found to occur more often in typical rebuilt barns (Næss and Bøe, 2010), the location of freestalls alone had no effect on milk yield.
The results of Simensen et al. (2010), showing increased milk yield with increasing herd sizes in small freestall dairy barns, may indicate an interaction between group size and space allowance. Seemingly, this effect also occurred in the present study, but when adjusting for other variables, the herd size effect disappeared. Interestingly, Petherick et al. (1983) pointed out that the need for space is greater in small groups, and the same principle is actually laid down in the European regulations for dry sows (EEC, 2001), where the unobstructed floor area must be increased by $10 \%$ for groups of fewer than 6 pigs. Still, there seems to be no scientific evidence to support this requirement in relation to pigs (Turner et al., 2003). Nevertheless, Morrison et al. (1981) found groups of 5 cattle to have less daily feed intake than a group of 10 cattle with the same space allocated per animal.

In the present study, one dead-end alley had no effect on the milk yield, whereas 2 or more dead-end alleys resulted in decreased milk yield for all parities. Cows seem to cope with one dead-end alley, probably because of the possibility of avoiding these areas in the barn. This supports recommendations that say that layouts with dead-end alleys should be avoided (Bickert et al., 2000; Smith et al., 2000).

The need for adequate space for cows with special needs is emphasized by several authors (Cook and Nordlund, 2004; Kammel and Graves, 2007). In the present study, there was insufficient space for special needs cows, and many farmers reported that they did not make use of these pens either. The present study indicates that this is not good practice.

The present study shows that primiparous cows benefit from water troughs located for easy access on the first freestall row. This supports the findings of Brouk et al. (2003) that water should be located for easy access and abundant availability, and those of Bickert et al. (2000) that more space and more locations should be provided when primiparous cows are housed with older cows. Water trough capacity below $47 \%$ of the recommended capacity was, in general, associated with 
lower milk yield. For water trough capacity below $80 \%$, milk yield decreased with increasing parity number. Sufficient water supply is essential in the lactating period (McFarland, 2000). Higher parities produce more milk, and seem to be more sensitive to water access.

Lower milk yield in cold buildings with natural ventilation was unexpected. High-yielding dairy cows have low lower critical temperature (Young, 1981), and comparable production results in insulated and cold buildings have been found (Zähner et al., 2004). Therefore, it is reasonable to assume that the result in the present study is influenced by other factors such as management routines and simple feeding systems, among others, on these farms.

\section{CONCLUSIONS}

In general, free space allocation has a limited effect on milk yield, but primiparous cows seem to benefit from increased space in small freestall herds. Layouts with 2 or more dead-end alleys are negative for milk yield, whereas feed bunk space, within the range of existing recommendations, does not affect productivity. Use of separation pens for special needs cows has a positive effect on milk yield. Milk yield is higher in herds with AMS, except for primiparous cows. Easy access to water troughs is important for primiparous cows, whereas sufficient water trough capacity seem to be essential for multiparous cows.

\section{ACKNOWLEDGMENTS}

The authors thank the participating farmers and the technicians, Stine Kvivesen, and Hans Kristian Hansen (North Trøndelag University College, Faculty of Agriculture and Information Technology, Steinkjer, Norway), for their help and support during the trial. The access to the data was given by the Norwegian Dairy Herd Recording System (NDHRS) and the Norwegian Cattle Health Services (NCHS) in agreement number 3/2006. The study was financially supported by grants from the Research Council of Norway, Agricultural Agreement Research Fund, and Foundation for Research Levy on Agricultural Products.

\section{REFERENCES}

ASABE. 2006. Terminology and recommendations for freestall dairy housing, freestalls, feed bunks and feeding fences. ASAE EP444.1 in ASABE Standards 2006. ASABE, St. Joseph, MI.

Bickert, W., B. Holmes, K. Janni, D. Kammel, R. Stowell, and J. Zulovich. 2000. Dairy Freestall Housing and Equipment, MWPS-7. MidWest Plan Service, Iowa State University, Ames.

Brouk, M., J. Harner III, and J. Smith. 2003. Effect of location of water access on water consumption of lactating cows housed in 2-and 4-row freestall buildings. In Proc. Fifth International Dairy Housing Conference, Fort Worth, TX.

Brumm, M. C., and P. S. Miller. 1996. Response of pigs to space allocation and diets varying in nutrient density. J. Anim. Sci. $74: 2730-2737$.

Caroprese, M., G. Annicchiarico, L. Schena, A. Muscio, R. Migliore, and A. Sevi. 2009. Influence of space allowance and housing conditions on the welfare, immune response and production performance of dairy ewes. J. Dairy Res. 76:66-73.

CIGR. 1994. The design of dairy cow housing. Report of the CIGR Section II Working group No 14, Cattle housing. Farm buildings research team. ADAS Bridgets Dairy Research Centre, Winchester, Hampshire, UK.

Cook, N. B., and K. V. Nordlund. 2004. Behavioral needs of the transition cow and considerations for special needs facility design. Vet. Clin. North Am. Food Anim. Pract. 20:495-520.

DeVries, T. J., and M. A. G. von Keyserlingk. 2006. Feed stalls affect the social and feeding behavior of lactating dairy cows. J. Dairy Sci. 89:3522-3531.

DeVries, T. J., M. A. G. von Keyserlingk, and D. M. Weary. 2004 Effect of feeding space on the inter-cow distance, aggression, and feeding behavior of free-stall housed lactating dairy cows. J. Dairy Sci. 87:1432-1438

Dohoo, I., W. Martin, and H. Stryhn. 2003. Veterinary epidemiologic research. AVC Inc., Charlottetown, Prince Edward Island, Canada.

Dozier, W. A. 3rd, J. P. Thaxton, J. L. Purswell, H. A. Olanrewaju, S. L. Branton, and W. B. Roush. 2006. Stocking density effects on male broilers grown to 1.8 kilograms of body weight. Poult. Sci. 85:344-351.

European Economic Community (EEC). 2001. Directive 91/630. Laying down minimum standards for the protection of pigs. In Official Journal of the European Communities, Brussels, Belgium.

Fisher, A. D., M. A. Crowe, P. O'Kiely, and W. J. Enright. 1997. Growth, behaviour, adrenal and immune responses of finishing beef heifers housed on slatted floors at 1.5, 2.0,2.5 or $3.0 \mathrm{~m}^{2}$ space allowance. Livest. Prod. Sci. 51:245-254.

Fregonesi, J. A., and J. D. Leaver. 2002. Influence of space allowance and milk yield level on behaviour, performance and health of dairy cows housed in strawyard and cubicle systems. Livest. Prod. Sci. $78: 245-257$.

Fregonesi, J. A., C. B. Tucker, and D. M. Weary. 2007. Overstocking reduces lying time in dairy cows. J. Dairy Sci. 90:3349-3354.

Friend, T. H., C. E. Polan, and M. L. McGilliard. 1977. Free stall and feed bunk requirements relative to behavior, production and individual feed intake in dairy cows. J. Dairy Sci. 60:108-116.

Gazzarin, C., and R. Hilty. 2002. Stallsysteme für Milchvieh: Vergleich der Bauinvestitionen. FAT Berichte Nr. 586. Eidgenössische Forschungsanstalt für Agrarwirtschaft und Landtechnik (ART), Tänikon, Ettenhausen, Switzerland.

Grant, R. J., and J. L. Albright. 2001. Effect of animal grouping on feeding behavior and intake of dairy cattle. J. Dairy Sci. 84(Suppl E):E156-E163.

Graves, R. E. 1989. Floor plans for cubicle housing of dairy cattle. Pages 1063-1070 in Proceedings of the 11th International Congress on Agricultural Engineering. V. A. Dodd and P. M. Grace, ed. A. A. Balkema Publishers, Dublin, Ireland.

Graves, R. E. 2000. Freestall barn layouts. Pages $57-71$ in Dairy Housing and Equipment Systems: Managing and Planning for Profitability (NRAES-129). Natural Resource, Agriculture, and Engineering Service, Ithaca, NY.

Henneberg, U., L. Munksgaard, E. Kristensen, S. Konggaard, and V. Østergaard. 1986. Malkekoens adfærd og produktion ved forskellig belægning i sengestalde (Behaviour and production of the dairy cow at different stocking rates in cubicle houses). Beretning nr. 613. Statens Husdyrbrugsfors $\varnothing g$ (National Institute of Animal Science), Denmark.

Huzzey, J. M., T. J. DeVries, P. Valois, and M. A. G. von Keyserlingk. 2006. Stocking density and feed barrier design affect the feeding and social behavior of dairy cattle. J. Dairy Sci. 89:126-133. 
Ingvartsen, K., and H. Andersen. 1993. Space allowance and type of housing for growing cattle: A review of performance and possible relation to neuroendocrine function. Acta Agric. Scand. A Anim. Sci. $43: 65-80$.

Kammel, D., and R. Graves. 2007. Planning and design considerations for transition and special needs cow housing. In Proc. Sixth International Dairy Housing Conference. Minneapolis, MN.

Kjæstad, H. P., and H. J. Myren. 2001a. Cubicle refusal in Norwegian dairy herds. Acta Vet. Scand. 42:181-187.

Kjæstad, H. P., and H. J. Myren. 2001b. Failure to use cubicles and concentrate dispenser by heifers after transfer from rearing accommodation to milking herd. Acta Vet. Scand. 42:171-180.

Krawczel, P. D., C. T. Hill, H. M. Dann, and R. J. Grant. 2008. Short communication: Effect of stocking density on indices of cow comfort. J. Dairy Sci. 91:1903-1907.

Krohn, C. C., and S. P. Konggaard. 1979. Effects of isolating firstlactation cows from older cows. Livest. Prod. Sci. 6:137-146.

McFarland, D. 2000. Feed area and water space design. Pages 297-314 in Dairy Housing and Equipment Systems. NRAES-129. Ithaca, $\mathrm{NY}$

Melin, M., G. G. N. Hermans, G. Pettersson, and H. Wiktorsson. 2006 Cow traffic in relation to social rank and motivation of cows in an automatic milking system with control gates and an open waiting area. Appl. Anim. Behav. Sci. 96:201-214.

Mentink, R. L., and N. B. Cook. 2006. Short communication: Feed bunk utilization in dairy cows housed in pens with either two or three rows of free stalls. J. Dairy Sci. 89:134-138.

Mogensen, L., L. H. Nielsen, J. Hindhede, J. T. Sorensen, and C. C. Krohn. 1997. Effect of space allowance in deep bedding systems on resting behaviour, production, and health of dairy heifers. Acta Agric. Scand. A Anim. Sci. 47:178-186.

Morrison, S. R., G. P. Lofgreen, and M. Prokop. 1981. Effect of floor space allotment and animal group size on beef cattle performance. Trans. ASABE 24:450-451.

Næss, G., and K. E. Bøe. 2010. Layouts and space allocation in Norwegian freestall dairy barns. Trans. ASABE 53:605-611.

NCR-89 Committee on Confinement Management of Swine. 1986. Effect of space allowance and tylosin feeding on performance of growing-finishing pigs. J. Anim. Sci. 62:871-874.

Olofsson, J. 1999. Competition for total mixed diets fed for ad libitum intake using one or four cows per feeding station. J. Dairy Sci. 82:69-79

Østerås, O., H. Solbu, A. O. Refsdal, T. Roalkvam, O. Filseth, and A. Minsaas. 2007. Results and evaluation of thirty years of health recordings in the Norwegian dairy cattle population. J. Dairy Sci. 90:4483-4497.

Petherick, J., S. Unit, and B. Craibstone. 1983. A biological basis for the design of space in livestock housing. Page 103 in Farm Animal Housing and Welfare. S. H. Baxter, M. R. Baxter, and J. A. C. MacCormack, ed. Martinus Nijhoff Publishers, Boston/The Hague/Dordrecht/Lancaster, for the Commission of the European Communities.

Pinheiro Machado Filho, L. C., D. L. Teixeira, D. M. Weary, M. A. G. von Keyserlingk, and M. J. Hötzel. 2004. Designing better water troughs: Dairy cows prefer and drink more from larger troughs. Appl. Anim. Behav. Sci. 89:185-193.

Simensen, E., O. Østerås, K. E. Bøe, C. Kielland, L. E. Ruud, and G. Næss. 2010. Housing system and herd size interactions in Norwegian dairy herds; associations with performance and disease incidence. Acta Vet. Scand. 52:14.

Smith, J. F., J. P. Harner III, M. J. Brouk, D. V. Armstrong, M. J. Gamroth, M. J. Meyer, G. Boomer, G. Bethard, and D. Putnam. 2000. Relocation and expansion planning for dairy producers. Kansas State University Agricultural Experiment Station and Cooperative Extension Service (MF2424, January 2000).Accessed May 2, 2010. http://www.ksre.ksu.edu/library/lvstk2/mf2424.pdf.

Spolders, M., U. Meyer, G. Flachowsky, and M. Coenen. 2004. Differences between primiparous and multiparous cows in voluntary milking frequency in an automatic milking system. Ital. J. Anim. Sci. $3: 167-176$

Svennersten-Sjaunja, K. M., and G. Pettersson. 2008. Pros and cons of automatic milking in Europe. J. Anim. Sci. 86(13 Suppl.):37-46.

Teixeira, D. L., M. J. Hötzel, and L. C. P. Machado Filho, 2006. Designing better water troughs: 2 . Surface area and height, but not depth, influence dairy cows' preference. Appl. Anim. Behav. Sci. 96:169-175.

Tucker, C. B., D. M. Weary, and D. Fraser. 2004. Free-stall dimensions: Effects on preference and stall usage. J. Dairy Sci. 87:12081216

Turner, S. P., D. J. Allcroft, and S. A. Edwards. 2003. Housing pigs in large social groups: A review of implications for performance and other economic traits. Livest. Prod. Sci. 82:39-51.

Young, B. A. 1981. Cold stress as it affects animal production. J. Anim. Sci. 52:154-163.

Zähner, M., L. Schrader, R. Hauser, M. Keck, W. Langhans, and B Wechsler. 2004. The influence of climatic conditions on physiological and behavioural parameters in dairy cows kept in open stables. Anim. Sci. 78:139-147. 